\title{
Re-description of Timarete punctata (Polychaeta: Cirratulidae) and its occurrence in the Mediterranean Sea
}

\author{
MELIH ERTAN ÇINAR \\ Ege University, Faculty of Fisheries, Dept. of Hydrobiology, 35100 Bornova, Izmir, Turkey. \\ E-mail: melih.cinar@ege.edu.tr
}

\begin{abstract}
SUMMARY: Timarete punctata (Grube, 1859) is re-described based on type material. In addition, a lectotype and paralectotype are designated for this species. Specimens of T. punctata collected from the western Atlantic, Indian Ocean and Mediterranean Sea were examined and their morphological characters compared using correlation and regression analysis. A number of characters were found to be size- dependent. The presence of T. punctata in the Levantine Sea (but not in the rest of the Mediterranean) suggests that it could be a Lessepsian species. This species might have previously been reported in the Levantine Sea as Cirriformia semicincta (Ehlers, 1905).
\end{abstract}

Keywords: Timarete punctata, description, lectotype, Lessepsian, Levantine Sea, eastern Mediterranean Sea, Turkey.

RESUMEN: REDESCRIPCIÓN DE TIMARETE PUNCTATA (PolychaETA: CiRRATUlidAe) Y SU APARICIÓN EN El MAR MEDITERRÁNeO. - Timarete punctata (Grube, 1859) se redescribe en base a material tipo. Adicionalmente, se designa un lectotipo y un paralectotipo para esta especie. Se examinaron especimenes de $T$. punctata recolectados del Atlántico oeste, océano Indico y mar Mediterráneo y sus caracteres morfológicos se compararon usando análisis de correlación y regresión. Se observó que una serie de caracteres eran dependientes de la talla. La presencia de T. punctata en la Cuenca Levantina (pero no en el resto del Mediterráneo) sugiere que podría tratarse de una especie Lessepsiana. Esta especie podría haber sido reportada previamente en la Cuenca Levantina como Cirriformia semicincta (Ehlers, 1905).

Palabras clave: Timarete punctata, descripción, lectotipo, Lessepsiana, Cuenca Levantina, Mediterráneo oriental, Turquía.

\section{INTRODUCTION}

The family Cirratulidae comprises 11 genera and 159 species worldwide (Beesley et al., 2000) and 10 genera and 21 species in the Mediterranean Sea (author's database). Cirratulids are known to occur in a variety of habitats from intertidal to abyssal depths (Blake, 1996). They are deposit feeders (Fauchald and Jumars, 1979) and have a wide range of reproductive characters (see Petersen, 1999) and modes of life. For instance, species of Dodecaceria construct burrows in calcareous structures such as shells, coral colonies and coralline algae (Gibson, 1978), while some other cirratulids form dense populations in organically polluted bottoms and have been considered as indicators of semi- or heavilypolluted zones in the marine environment (Pearson and Rosenberg, 1978; Bellan, 1984).

In spite of their importance in marine benthic communities, the real diversity of the family is not adequately known in most parts of the world's oceans. Species such as Chaetozone setosa Malmgren, 1867, Cirriformia tentaculata (Montagu, 1808) and Timarete filigera (Delle 
Chiaje, 1828) have been reported elsewhere and considered as "cosmopolitan" species. However, this assumption may be incorrect and, at least in the case of $C$. setosa, examining extensive material from the eastern and western Mediterranean reveals that this species (frequently reported in polluted bottoms, e.g. Bellan, 1984; Ergen, 1992; Simboura et al., 1995) does not occur in the Mediterranean Sea (personal observations).

Cirratulids inhabiting the Mediterranean Sea have rarely been a subject of special interest and have been reported in general ecological works. Consequently, most records on cirratulids require reexamination to confirm if they occur in the region. For example, Timarete anchylochaeta (Schmarda, 1861) and T. dasylophius (Marenzeller, 1879) were only reported from the Sea of Marmara (Rullier, 1963), and have not been subsequently cited in other Mediterranean basins. However, Laubier (1961) and more recently Gherardi et al. (2007) studied Monticellina species and the schizogenesis of Timarete filigera in this region respectively.

When sorting material collected during a project funded by TUBITAK (The Scientific and Technological Research Council of Turkey, Project No: 104Y065) to investigate zoobenthic communi- ties and the possible presence of alien species along the Turkish Levantine coast, a total of 27 juvenile and adult specimens of a species belonging to the genus Timarete was found. Examination of the specimens revealed that they do not belong to any species of Timarete previously recorded in the Mediterranean Sea (Timarete anchylochaeta, T. dasylophius, T. dollfusi (Fauvel, 1928) and T. filigera). Conversely, their morphological features matched well with those of Timarete punctata (Grube, 1859), which was originally described from the Caribbean.

The original and subsequent descriptions of Timarete punctata are poor, mostly emphasizing its characteristic colour markings. This paper focuses on re-describing T. punctata based on type and nontype specimens. A lectotype and paralectotype are designated among the syntypes of $T$. punctata, and specimens of $T$. punctata collected from different parts of the world are compared.

\section{MATERIAL AND METHODS}

The Mediterranean specimens of Timarete punctata were collected in Çevlik Harbour (Levantine

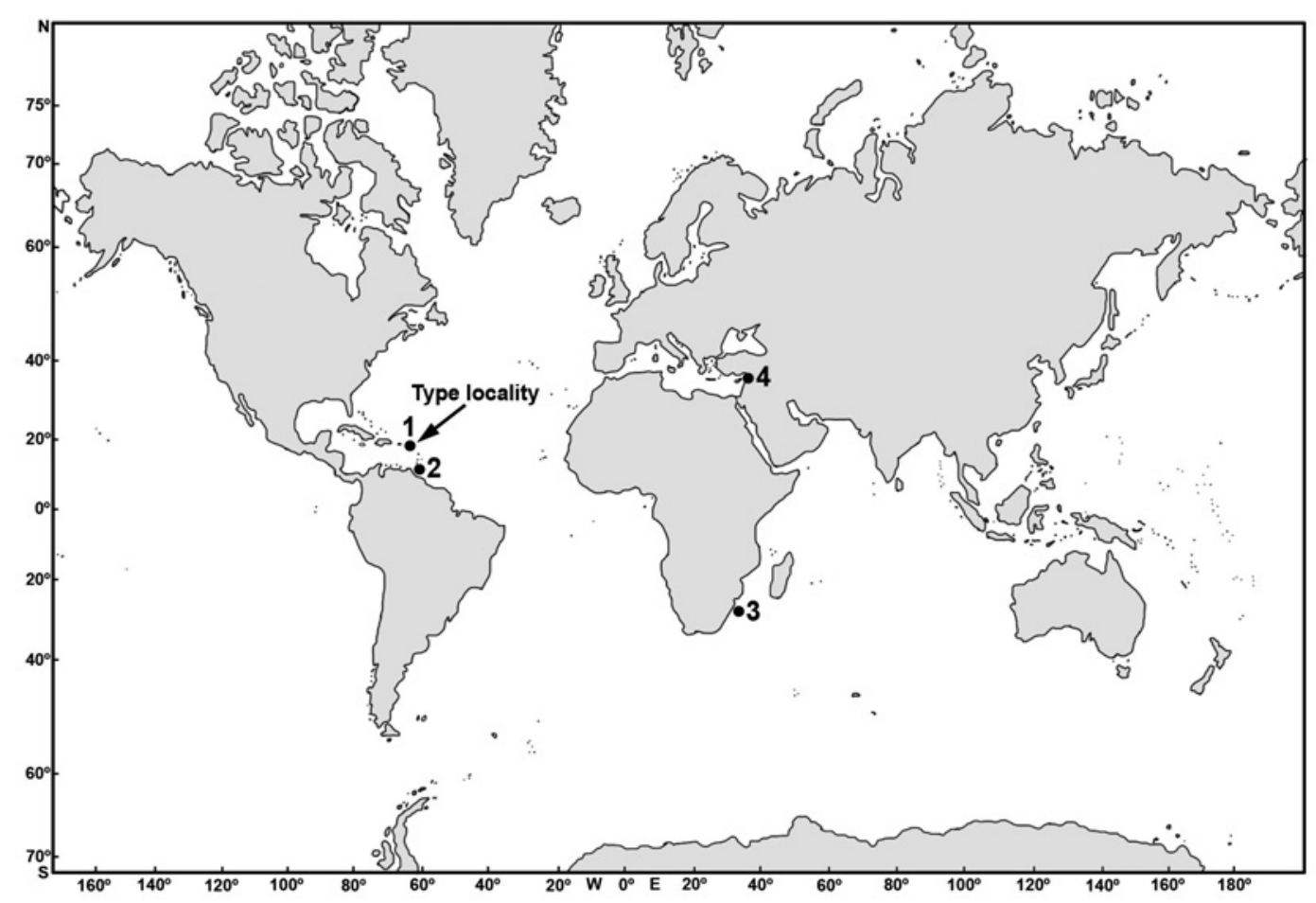

FIG. 1. - Location of the examined specimens of Timarete punctata. 1. St Croix, Christiansted (US Virgin Islands), 2. Tobago, 3. Isipingo Beach, Durban, South Africa, 4. Turkey, Levantine Sea. 


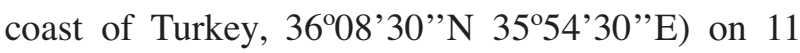
September 2005 (Fig. 1), from a submerged tyre. The material on and in the tyre was scraped and placed in jars containing $4 \%$ formaldehyde solution in seawater. In the laboratory, samples were washed with tap water, sorted according to major systematic groups under a stereomicroscope and then preserved in $70 \%$ ethanol. Specimens of T. punctata were identified and counted under stereo- and compound microscopes.

The type material deposited at the Zoological Museum of Copenhagen (ZMUC) and additional non-type material (collected on the coasts of South Africa and Tobago) deposited at the Natural History Museum, London (NHM) were also examined (Fig. 1).

A number of metric and meristic characters such as body length, body width, number of chaetigers, number of acicular spines and capillary chaetae on anterior, middle and posterior parapodia, chaetigers bearing tentacular filaments etc. were recorded on all unbroken type and non-type specimens examined (25 specimens). Total body length, width at chaetigers 5 (excluding chaetae) and oocyte diameters were measured with an ocular micrometer.

Regression and pearson-moment correlation analyses were used to determine if the biometrical characters such as the number of chaetigers, the first occurrence of noto- and neuropodial acicular spines on the body, and the number of acicular spines on anterior and posterior parapodia are sizedependent or not. All data were normally distributed (Kolmogorov-Smirnov test); therefore, the data was not transformed prior to analysis. In the analyses, the specimens of Timarete punctata from different parts of the world including type material were evaluated together because the number of specimens of $T$. punctata from the Indian Ocean (one specimen) and the western Atlantic Ocean (3 specimens) was too low to perform a statistical analysis. However, the data from the different populations are shown with a different symbol in the figures (see Fig. 6).

Drawings were made with the aid of a cameralucida. Photographs of specimens were taken with a digital camera (Olympus, Camedia, C-7070), attached to stereo- and compound microscopes.

The Mediterranean specimens of Timarete punctata were deposited at the Museum of the Faculty of Fisheries (ESFM), Ege University, Turkey.

\section{RESULTS AND DISCUSSION}

Timarete punctata (Grube, 1859)

(Figs. 2-5)

Cirrhatulus punctata Grube, 1859: 107.

Cirrhatulus nigromaculatus Grube, 1869: 24-25.

Cirratulus punctatus; Augener, 1918: 465-467

Audouinia punctata; Day, 1949: 448; Tebble, 1955: 126-127.

Cirriformia punctata; Hartman, 1956: 292; Day, 1962: 648; Hartman, 1966: 227; Gibbs, 1971: 179; Fauchald, 1977: 50; Hartmann-Schröder, 1992: 71.

Timarete punctata; Petersen, 1999: 116.

Type materials. ZMUC-POL-261, St Croix, Christiansted (US Virgin Islands, Atlantic Ocean), 18.9.1845, coll. Krøyer, here designated as the Lectotype. ZMUC-POL-1837, St Croix, Christiansted (US Virgin Islands, Atlantic Ocean), 18.9.1845, coll. Krøyer, one specimen, here designated as the Paralectotype.

Non-type materials. INDIAN OCEAN: NHM 1936.10.16.147, Isipingo Beach, Durban, South Africa, donated by Prof. T.A. Stephenson, one specimen; WESTERN ATLANTIC OCEAN: NHM 1931.6.22.3, Tobago, collected by Capt. A.K. Totton's West Indian Expedition, three specimens; MEDITERRANEAN SEA: ESFM-POL/05-156, 11.9.2005, Levantine coast of Turkey, Çevlik Harbour, $0.2 \mathrm{~m}$, on a submerged tyre, 27 specimens, coll. $104 \mathrm{Y} 065$ TUBITAK Project.

Description of the lectotype. Lectotype complete, small, $6.5 \mathrm{~mm}$ long, $0.82 \mathrm{~mm}$ wide, with 70 chaetigers (Figs. 2A, 3A, B). Paralectotype complete, small, $4.5 \mathrm{~mm}$ long, $0.6 \mathrm{~mm}$ wide, with 50 chaetigers (Fig. 3C). Body elongated, thickened throughout with short, crowded segments, tapering posteriorly, with a shallow ventral groove (Figs. 2A, 3A, B). Background colour dark brownish, with black irregular spots on dorsal and ventral body surfaces; tentacular filaments pale brownish, with few black lateral stripes; anterior branchiae pale brownish, middle and posterior branchiae dark brownish with irregular black spots (Figs. 2A, 3A, B)

Prostomium triangular, broad, bluntly pointed on anterior margin, wider than long; eyes absent. Peristomium short, about 1.5 times longer than prostomium, with two distinct annulations. Tentacular filaments present on chaetigers 3 and 4 , forming two distinct groups, each with five filaments. Branchiae present from chaetiger 1 to posterior segments, branchiae located just dorsal to notopodia from chaetigers one to 10 ; from chaetiger 10 to 26 , branchiae gradually moving to dorsal midline of body; from chaetigers 26 to 42 , branchiae gradually moving to notopodia again; after chaetiger 42 to end of body, branchiae located just dorsal to notopodia (Fig. 2A).

Notopodia and neuropodia widely separated, poorly developed. Capillary chaetae present both on noto- and neuropodium of each chaetiger. 


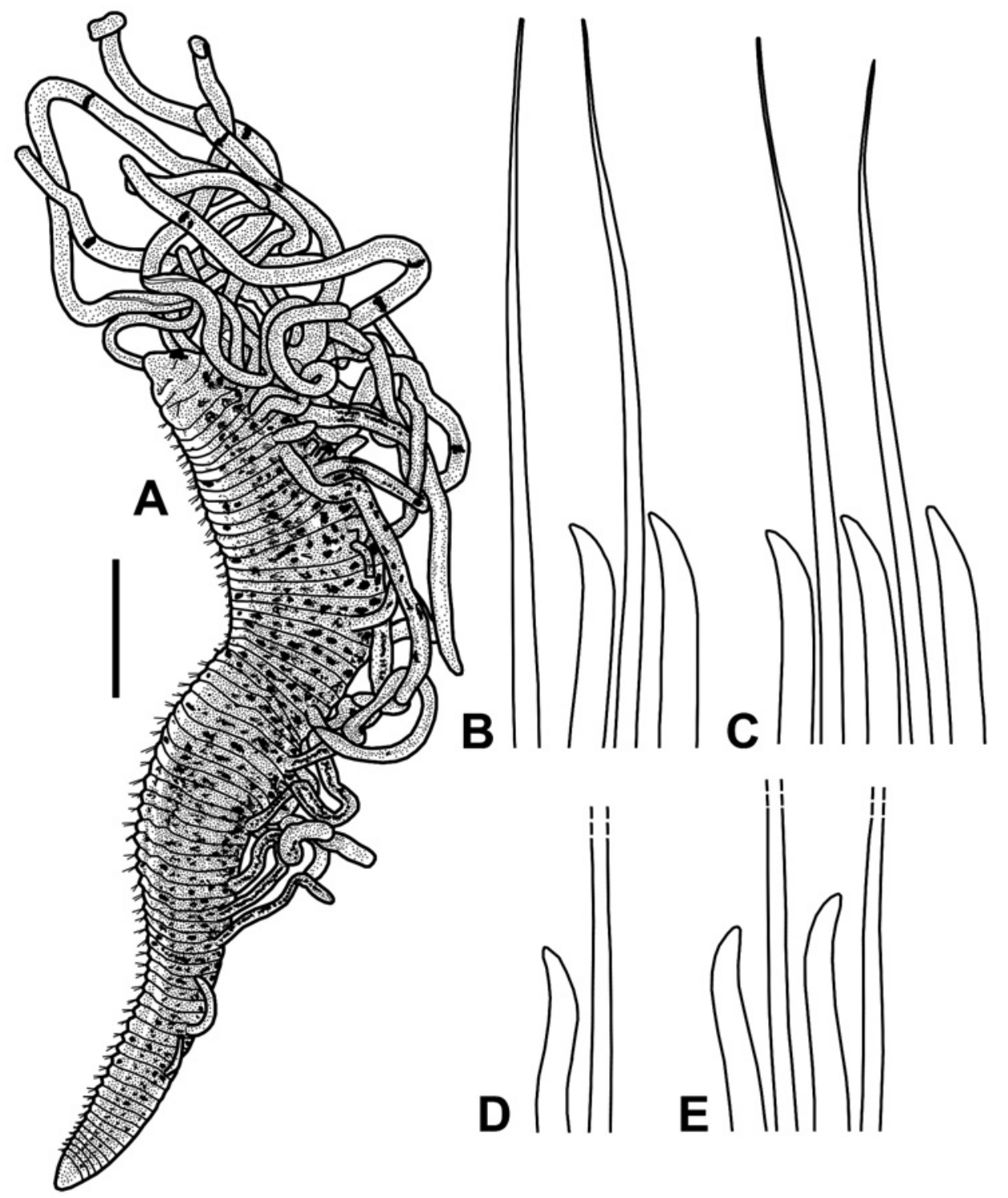

FIG. 2. - Timarete punctata, Lectotype (ZMUC-POL-261). A, lateral view of body; B, chaetae on notopodium of an anterior chaetiger; C, chaetae on neuropodium of an anterior chaetiger; D, chaetae on notopodium of a posterior chaetiger; E, chaetae on neuropodium of a posterior chaetiger. Scale bar: $\mathrm{A}=0.8 \mathrm{~mm}, \mathrm{~B}-\mathrm{E}=20 \mu \mathrm{m}$.

Acicular spines first present on notopodium of chaetiger 8 , and on neuropodium of chaetiger 6 ; pale brown; numbering two on notopodia and three on neuropodia of anterior chaetigers, accompanied by two capillaries; numbering two on noto- and neuropodia of middle chaetigers, accompanied by two capillaries; and numbering one on notopodia and two on neuropodia of posterior chaetigers, accompanied by one and two capillaries respectively. Acicular spines slightly sigmoid, with truncated tips (Figs. 2B-D). Acicular spines about one third of length of capillaries.

Pygidium somewhat triangular; anal opening placed dorsally (Fig. 2A).
Reproduction. The reproductive features of Timarete punctata are poorly known. The only data available are from the study by Petersen (1999), who observed an Australian specimen with the anterior and posterior ends regenerating, which led her to point out asexual reproduction by fusion for this species. A regenerated specimen was also found among the Mediterranean material. In addition, one specimen had oocytes in the coelom (mean diameter $=65.53 \mu \mathrm{m} \pm 1.21$, minimum and maximum $=50$ $80 \mu \mathrm{m}, \mathrm{n}=30$ )

Remarks. The type specimens are small. They seem to be juveniles without reproductive products. 

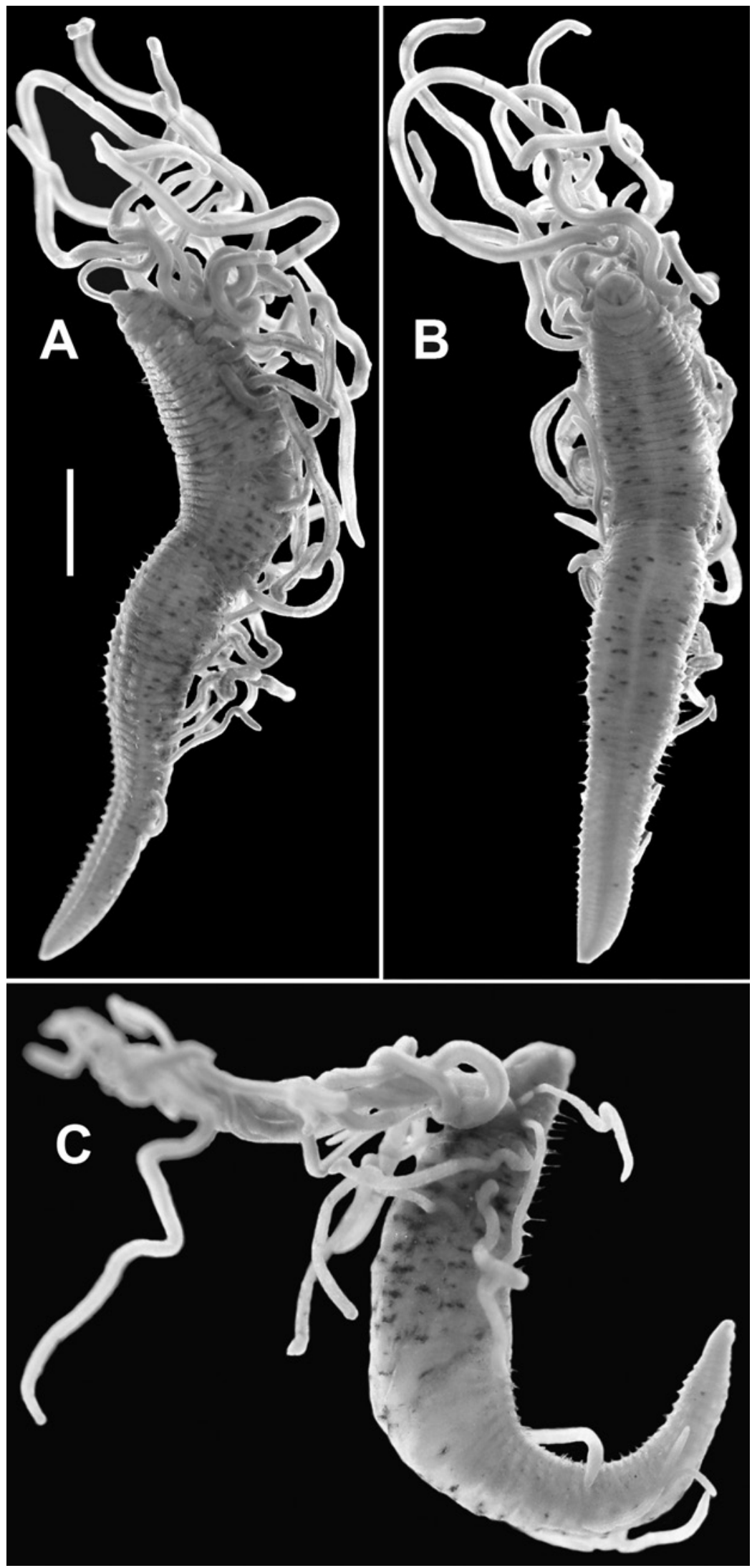

FIG. 3. - Timarete punctata. A, lateral view of Lectotype (ZMUC-POL-261); B, ventral view of Lectotype (ZMUC-POL-261); C, dorsal view of Paralectotype (ZMUC-POL-1837). Scale bar: A and B=0.8 $\mathrm{mm}, \mathrm{C}=0.7 \mathrm{~mm}$. 

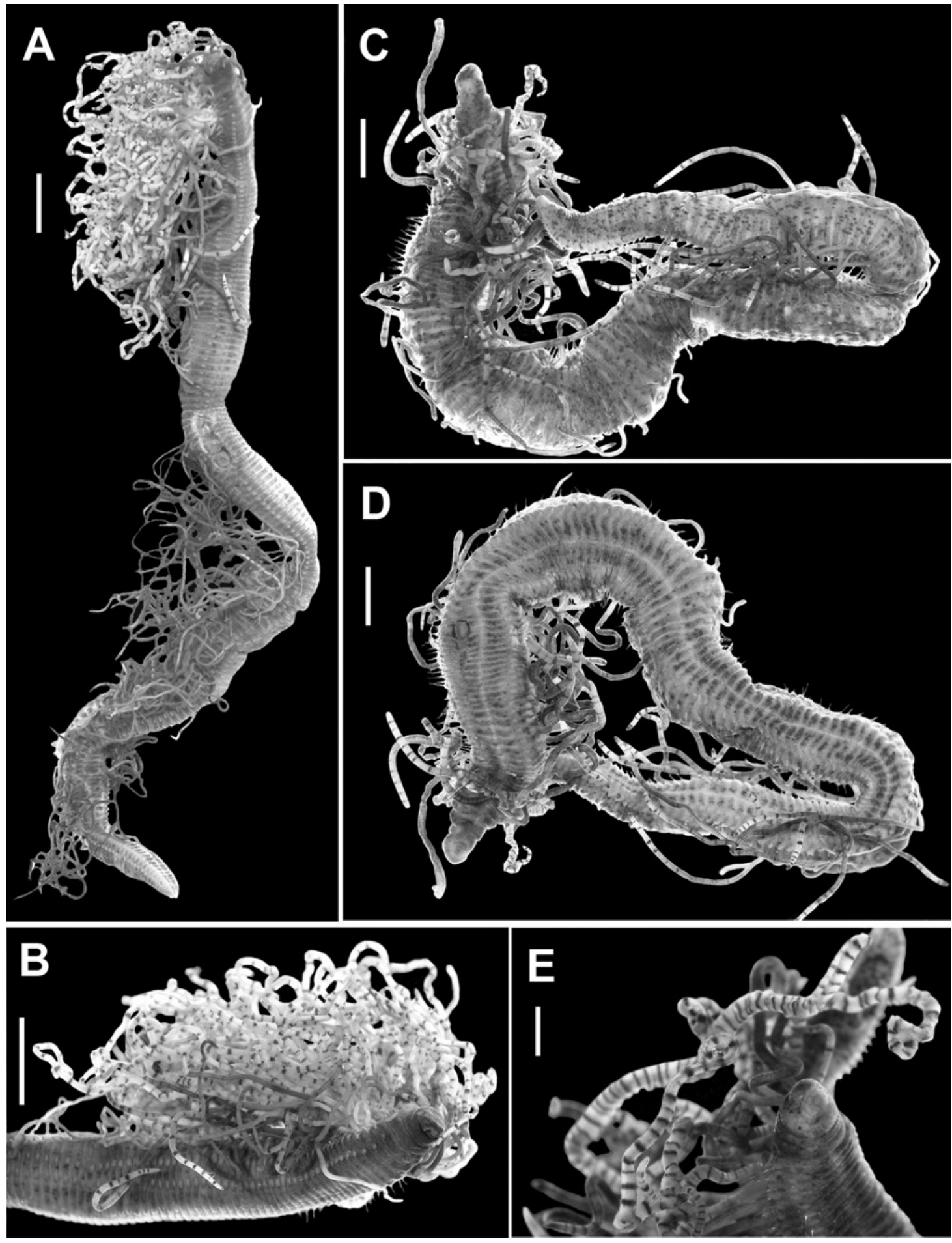

FIG. 4. - Timarete punctata. A, lateral view of the specimen from the Indian Ocean (NHM 1936.10.16.147); B, anterior part of the specimen from the Indian Ocean; C, dorsal view of a Mediterranean specimen (ESFM-POL/05-156); D, ventral view of a Mediterranean specimen; E, antero-ventral region of a Mediterranean specimen. Scale bar: A and B= $3 \mathrm{~mm}, \mathrm{C}$ and $\mathrm{D}=1.6 \mathrm{~mm}, \mathrm{E}=1 \mathrm{~mm}$.

The other specimens examined were larger; the largest Mediterranean specimen was $43.5 \mathrm{~mm}$ long, with 170 chaetigers, the South African specimen was $50 \mathrm{~mm}$ long with 176 chaetigers (Fig. 4A) and the western Atlantic specimen was $20.3 \mathrm{~mm}$ with 78 chaetigers. A significant positive linear regression was found between the number of chaetigers and the body length (Fig. 6). The number of acicular spines on parapodia, first appearance of acicular spines on chaetigers and number of chaetigers involving ten- 

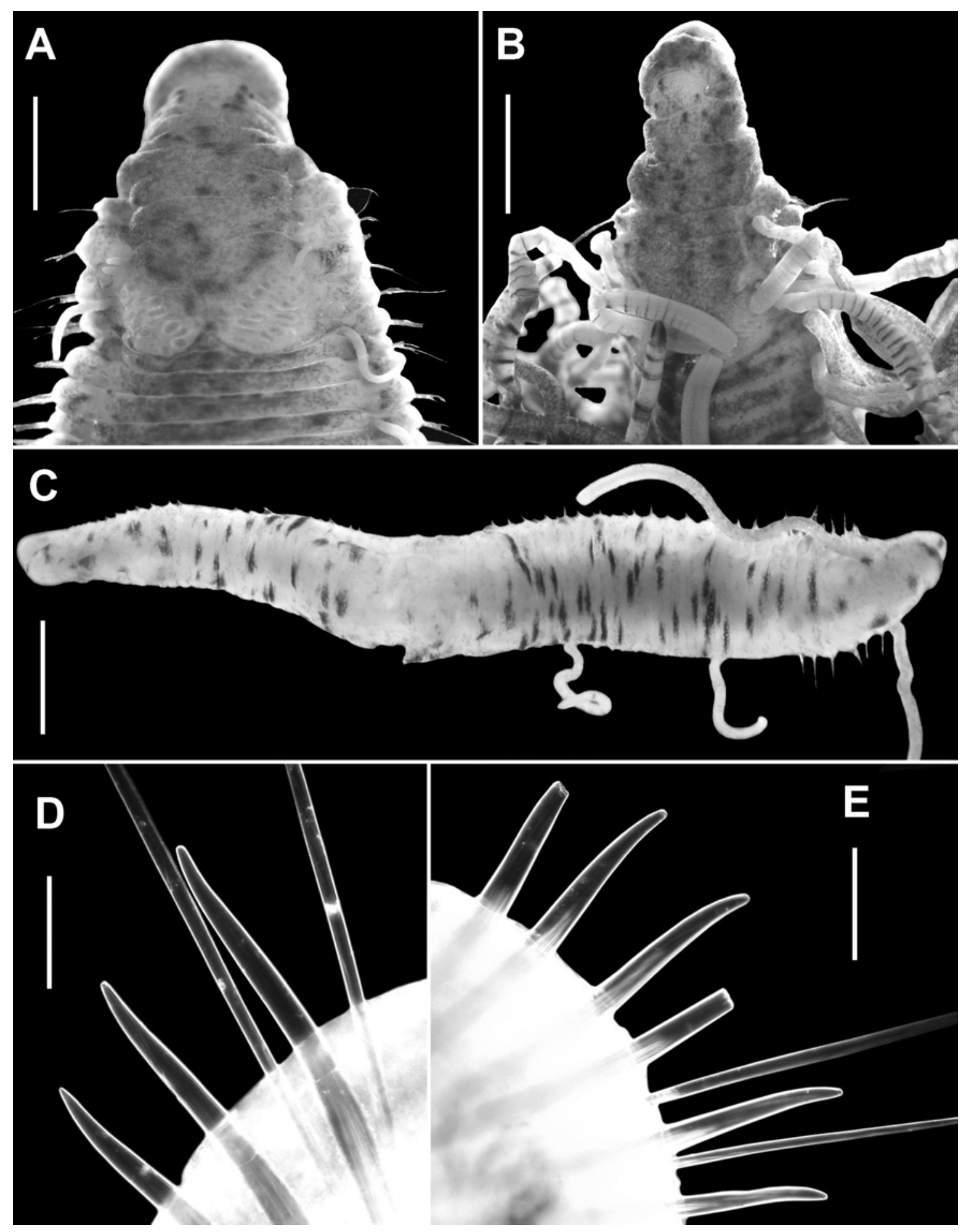

FIG. 5. - Timarete punctata. A, antero-dorsal region of a Mediterranean specimen (ESFM-POL/05-156); B, antero-dorsal region of a Mediterranean specimen; C, a juvenile specimen from the Mediterranean Sea; D, chaetae on neuropodium of an anterior chaetiger of the largest Mediterranean specimen; E, chaetae on neuropodium of a posterior chaetiger of the largest Mediterranean specimen. Scale bars: A-C = $1 \mathrm{~mm}$, $\mathrm{D}$ and $\mathrm{E}=25 \mu \mathrm{m}$.

tacular filaments, which are of taxonomic importance in Cirratulidae, varied considerably among the specimens examined. For example, the Lectotype has three and two acicular spines on the anterior and posterior neuropodia (Fig. 3B-E) respectively, whereas the largest Mediterranean specimen has six and three acicular spines on the anterior and posterior neuropodia respectively (Fig. 5 D-E). Acicular spines were first seen on neuropodia of chaetiger 6 in the Lectotype vs. chaetiger 17 in the largest 
Mediterranean specimen. Acicular spines commenced on chaetiger 12 in specimens collected off west Africa (Day, 1949) and on chaetiger 9 in specimens (15 to $32 \mathrm{~mm}$ long) from Hawaiian Islands (Hartman, 1966). However, regression and correlation analyses show that many characters are sizedependent (Fig. 6), so increasing body length results in an increased number of acicular spines on parapodia and the appearance of acicular spines on the most posterior chaetigers. The morphology of chaetae on parapodia is similar for specimens collected from different regions. Some specimens, including type material and juveniles from the Mediterranean, have acicular spines that are more curved than those on mature specimens. The black lateral stripes on the tentacular filaments and branchiae, which are obvious in non-type material (Figs. 4A-E), were faded on type specimens, probably due to the long time spent in alcohol. In the largest specimen from South Africa, branchiae on middle and posterior parapodia are densely pigmented, with relatively fewer black spots (Fig. 4A). Juvenile forms of $T$. punctata have a few, elongated black spots on a yellowish body (Fig. 5C), whereas mature specimens have numerous, somewhat rounded black spots on a dark brownish body. The number of tentacular filaments also varies between small and large specimens; numbering 10 on the Lectotype $(6.5 \mathrm{~mm}$ long) and approximately 60 on the largest Mediterranean specimen (43.5 $\mathrm{mm}$ long) (Fig. 5A, B). The tentacular filaments emerge on chaetigers 2 and 3 in juvenile specimens compared to chaetigers 3-5 in mature specimens. Correlation analysis showed that increasing body size leads to tentacular filaments occurring more posteriorly on the body $(\mathrm{r}=0.84, \mathrm{p}<0.05)$. However, specimens larger than $7 \mathrm{~mm}$ have tentacular filaments on chaetigers 3-5.

Timarete punctata, originally described from the coast of St. Croix, Christiansted (US Virgin Islands, Atlantic Ocean), is characterized by black spots on the body, tentacular filaments and branchia (Grube,1859; this study). It was previously reported in the western Atlantic (Grube, 1859; Hartman, 1956; 1966; Fauchald, 1977), in the eastern Atlantic (Augener, 1918; Day, 1949; Tebble, 1955), the western Indian Ocean (Day, 1962; Amoureux, 1974) and the Pacific Ocean (Gibbs, 1971; Hartmann-
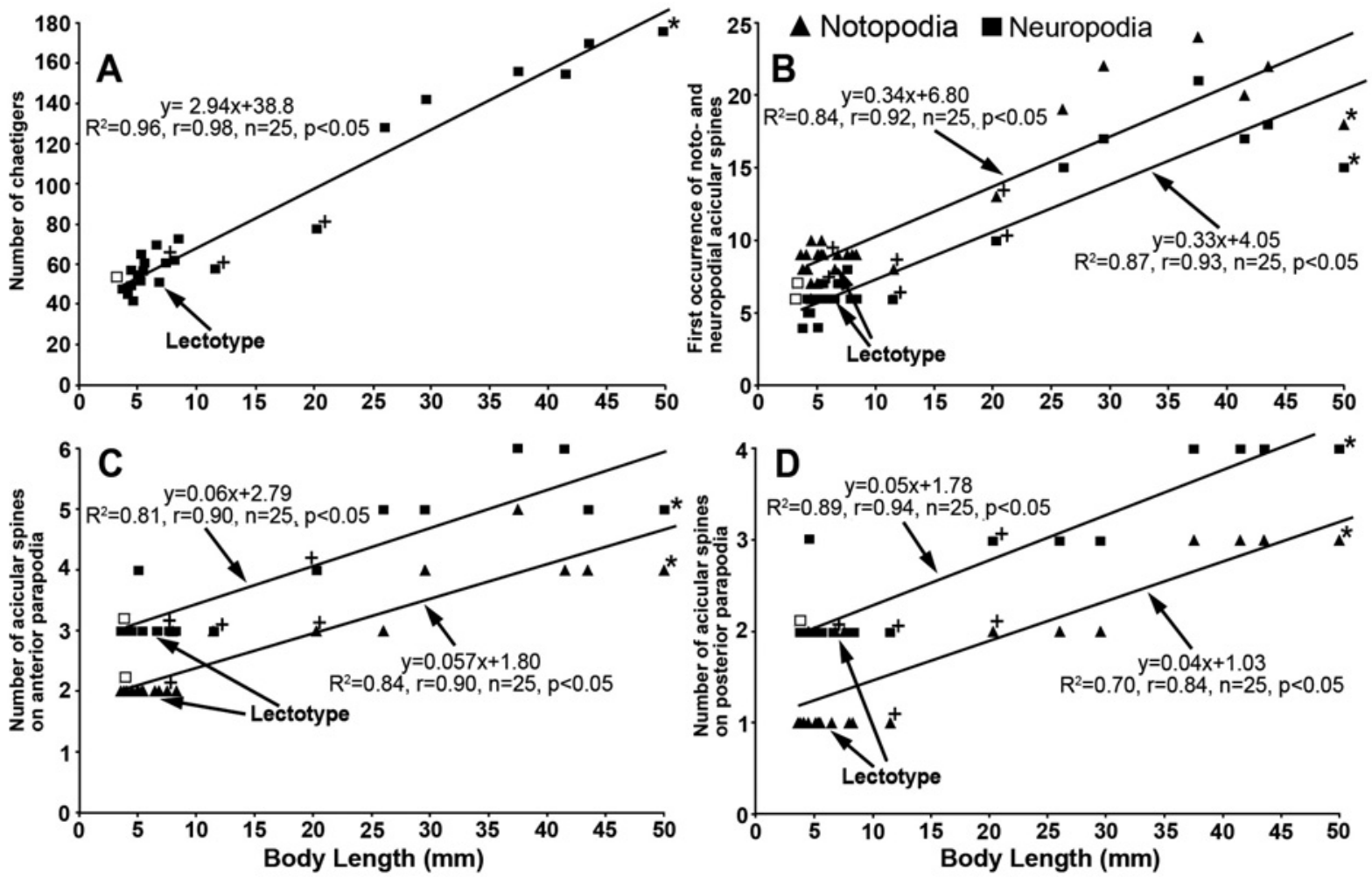

FIG. 6. - Relationships between body length of Timarete punctata and number of chaetigers (A), first occurrence of noto- and neuropodial acicular spines (B), number of acicular spines on anterior parapodia (C), and number of acicular spines on posterior parapodia (D). ( Paralectotype, + specimens from the western Atlantic Ocean, * specimen from the Indian Ocean, other data points belong to the Mediterranean specimens). 
Schröder, 1992, Petersen, 1999). Later, Grube (1869) described a new species, Cirrhatulus nigromaculatus, from the Red Sea. Treadwell (1901) also described a new cirratulid species from the coast of Puerto Rico (western Atlantic) and named it in the same way as Grube did in 1869, Cirrhatulus nigromaculata. The situation was outlined by Augener (1918): "Der C. nigromaculata von Porto Rico ist nach seiner Benennung und kurzen Beschreibung wohl dieselbe wie Grube's und meine Art. Treadwell errichtete die Art als neu, der name "nigromaculatus" wurde aber von Grube bereits 1869 für einen Cirratulus des Roten Meeres verwendet; demnach ist die Treadwell'sche Art einzuziehen und die Bezeichnung "punctatus" anzunehmen". As "Cirrhatulus" nigromaculatus shows very close morphological affinity with $T$. punctata (especially colour pattern), it was subsequently synonymized with T. punctata (Augener, 1918; Hartman, 1956). When the records of $C$. nigromaculatus are taken into account, the distributional range of T. punctata extends to the Red Sea. Day (1962) and HartmannSchröder (1992) postulated that T. punctata is a circumtropical and subtropical species. However, this generalization might be incorrect, as it has not been reported in the Mediterranean and eastern Atlantic before. In previous studies, this species was collected on both soft and hard substrata in shallow waters.

Timarete punctata has not been reported in the Mediterranean Sea before. However, Laubier (1966) found a large specimen $(8 \mathrm{~cm})$ in 1965 on rocks with algae in the mediolittoral zone of the Lebanon coast and identified it as Cirriformia semicincta (Ehlers, 1905). He described the specimen as "Un très grand exemplaire de près de $8 \mathrm{~cm}$ de longueur, caractérisé par la coloration en anneaux alternativement sombres et clairs des filaments tentaculaires et des branchies. Le corps est également parsemé de points sombres sur un fond plus clair". However, the original and subsequent descriptions of $C$. semicincta show that it has black pigmentations only on the ventral side of the body and does not have black spots on the dorsum of the body, tentacular filaments or branchiae (Ehlers, 1905; Fauvel, 1953). The features of Laubier's specimen indicate that this specimen might in fact belong to T. punctata, not to C. semicincta. Although this study reports the first occurrence of $T$. punctata in the Mediterranean Sea, it might have been present in the region for a long time.

The presence of Timarete punctata in the Levantine Sea and the Red Sea (cited under the name of Cirrhatulus nigromaculatus) suggests that this species might be a Lessepsian migrant (a species which migrated from the Red Sea to the Mediterranean through the Suez Canal). The absence of this species among the extensive material previously collected from the Aegean Sea supports this hypothesis. Monticellina dorsobranchialis (Kirkegaard, 1959), Timarete anchylochaeta and T. dasylophius (Rullier, 1963; Laubier, 1966; BenEliahu, 1972) were also reported as alien Mediterranean species. However, Çinar et al. (2005) demonstrated just the contrary for $M$. dorsobranchialis and questioned the occurrence of T. anchylochaeta and T. dasylophius in the Mediterranean Sea.

The present study enhances our knowledge of the morphology and reproductive features of Timarete punctata. As it could be an alien Mediterranean species, its functional role in the prevailing ecosystem as well as its possible impacts on the native fauna are certainly an interesting topic to be investigated in future studies.

\section{ACKNOWLEDGMENTS}

I am much indebted to Dr. Danny Eibye Jacobsen (ZMUC, Denmark) for loaning type-specimens of Timarete punctata, to Emma Sherlock (NHM, United Kingdom) for loaning specimens of T. punctata from South Africa and Trinidad Tobago, to Dr. Susan Chambers (NMS, United Kingdom) for correcting the English of the text and to colleagues at the Department of Hydrobiology, Ege University for their help in collecting and sorting the benthic material. Also to two anonymous referees for their constructive comments on the manuscript. This work was financially supported by TUBITAK (Project Number: 104Y065)

\section{REFERENCES}

Amoureux, L. - 1974. Annélides Polychètes de Madagascar recueillies par G. Cherbonnier en 1960. Bull. Mus. Hist. Nat., Paris 3, zool. 145: 425-462.

Augener, H. - 1918. Polychaeta. Beit. Ken. Meer. Westafrikas, 2: 67-625.

Beesley, P.L., G.J.B. Ross and C.J. Glasby (eds.). - 2000. Polychaetes and Allies: The Southern Synthesis. Fauna of Australia. Vol. 4A Polychaeta, Myzostomida, Pogonophora, Echiura, Sipuncula. CSIRO Publishing: Melbourne xii 465 pp.

Bellan, G. - 1984. Indicateurs et indices biologiques dans le domaine marin. Bull. Ecol., 15: 13-20.

Ben-Eliahu, M.N. -1972. Some Polychaeta Errantia from the Suez Canal. Isr. J. Zool., 21: 189-203. 
Blake, J.A. - 1996. 8. Family Cirratulidae Ryckholdt, 1851. Including a revision of the genera and species from the eastern North Pacific. In: J. A. Blake, B. Hilbig and P.H. Scott (eds.), Taxonomic Atlas of the Benthic Fauna of the Santa Maria Basin and the Western Santa Barbara Channel. Volume 6 - The Annelida Part 3, Polychaeta: Orbiniidae to Cossuridae. Santa Barbara Museum of Natural History, pp. 263-384. Santa Barbara, California.

Çinar, M.E., M. Bilecenoglu, B. Oztürk, T. Katagan and V. Aysel. - 2005. Alien species on the coasts of Turkey. Med. Mar. Sci., 6: $119-146$.

Day, J.H. - 1949. On the Polychaeta collected by Mr. J. Colman at St. Helena. Zool. J. Linn. Soc., 41: 434-451

Day, J.H. - 1962. Polychaeta from several localities in the western Indian Ocean. Proc. Zool. Soc. Lond., 139: 627-656.

Ehlers, E. - 1905. Anneliden der Sammlung Schauinsland. Ergebnisse einer Reise nach dem Pacific. Schauinsland 1896/97. Zool. Jahrb. Abt. Syst. Ekol. Geogr. Tiere, 22: 281302 .

Ergen, Z. - 1992. The latest status of Polychaeta in the soft substrate of Izmir Bay. Rapp. Comm. Int. Mer Médit., 33.

Fauchald, K., P. Jumars. - 1979. The diet of worms: A study of polychaete feeding guilds. Oceanogr. Mar. Biol., 17: 193-284.

Fauchald, K. - 1977. Polychaetes from intertidal areas in Panama, with a review of previous shallow-water records. Smithson. Contrib. Zool., 221: 1-81.

Fauvel, P. - 1953. Annélides Polychètes Non Pélagiques. Exp. Océanogr. Côt. Afric. Atlant. Sud Inst. Roy. Sci. Nat. Belg., 4: $1-56$.

Gherardi, M., M. Sciscioli, E. Lepore, G. Todisco and A. Giangrande. - 2007. The role of schizogenesis in population dynamics of Timarete filigera (Polychaeta: Cirratulidae): 2years observations in the Port of Bari (South Adriatic Sea). Mar. Ecol., 28: 306-314.

Gibbs, P.E. - 1971. The polychaete fauna of the Solomon Islands. Bull. Br.Mus. (Nat. Hist.) Zool., 21: 101-211.

Gibson, P.H. - 1978. Systematics of Dodecaceria (Annelida: Polychaeta) and its relation to the reproduction of its species. Zool. J. Linn. Soc., 63: 275-287.

Grube, A.E. -1856-59. Annulata Örstediana. Pt. 1, pp. 44-62, 1856. Pt. 2, pp. 158-186, 1857. Pt.3, pp. 105-120, 1859. Viden. Medd. Dansk naturhist. For. Köbenhavn.
Grube, A.E. - 1869. Beschreibungen neuer oder weniger bekannter von Hrn. Ehrenberg gesammelter Anneliden des rothen Meeres. Monat. Kon. Preus. Akad. Wiss. Berlin: 484-521.

Hartman, O. - 1956. Polychaetous annelids erected by Treadwell, 1891 to 1948 , together with a brief chronology. Bull. Am. Mus. Nat. Hist., 109: 239-310.

Hartman, O. - 1966. Polychaetous annelids of the Hawaiian Islands. Occas. Pap. Bern. P. Bishop Mus., 23: 163-252.

Hartmann-Schröder, G. - 1992. Zur Polychaetenfauna der Polynesischen Inseln Huahiné (Gesellschafts inseln) und Rangiroa (Tuamotu-Inseln). Mitt Hamburg. Zool. Mus. Ins., 89: 49-84.

Laubier, L. - 1961. Monticellina heterochaeta n.g., n.sp., Cténodrilidé (Polychètes sédentaires) des vases cotières de Banyuls-sur-Mer. Vie Milieu, 11: 601-604.

Laubier, L. - 1966. Sur quelques annélides polychètes de la région de Beyrouth. Misc. Pap. Nat. Sci. Am. Univ. Beirut, 5: 1-14.

Pearson, T.H. and R. Rosenberg. - 1978. Macrobenthic succession in relation to organic enrichment and pollution of the marine environment. Oceanogr. Mar. Biol. Annu. Rev., 16: 229-311.

Petersen, M.E. - 1999. Reproduction and development in Cirratulidae (Annelida: Polychaeta). In: A.W.C. Dorresteijn and W. Westheide (eds.). Reproductive strategies and developmental patterns in Annelids, pp. 107-128. Hydrobiologia, Amsterdam.

Rullier, F. - 1963. Les Annélides Polychètes du Bosphore, de la Mer de Marmara et de la Mer Noire, en relation avec celles de la Méditerranée. Rap. Com. Int. Mer Médit., 17: 161-260.

Simboura, N., A. Zenetos, P. Panayotidis and A. Makra. - 1995. Changes in benthic community structure along an environmental pollution gradient. Mar. Poll. Bull., 30: 470-474.

Tebble, N. -1955 . The polychaete fauna of the Gold Coast. Bull. Br. Mus. (Nat. Hist.) Zool., 3: 59-148.

Treadwell, A.L. - 1901. The Polychaetous annelids of Porto Rico. Bull. US Fish Comm., 20: 181-210.

Scient. ed.: D. Martin.

Received November 23, 2006. Accepted June 22, 2007. 